\title{
Synthesis of Furopyrimidine Derivatives
}

Mohamed. A.El-Megid Abdel-Hamid', Azza Mohamed El-Kazak ${ }^{1}$,Magdy,Hamed Seada ${ }^{1}$ and Osama Mohamed Farouk ${ }^{1}$

1.Chemistry Department, Faculty of Education, Roxy, Cairo, A. R. Egypt

${ }^{*}$ Chemistry Department, Faculty of Science and Humanities, Shaqra University, KSA

E mail:mabdelmegid@yahoo.com

\begin{abstract}
Furopyrimidines have been known for many years and have been thoroughly examined in the recent years. The present review deals with description of the various synthetic routes for furopyrimidine derivatives.
\end{abstract}

Keywords: Furopyrimidines,synthesis, biological importance.

Table of Contents

1 Synthesis of Furopyrimidine Derivatives

1.1. From Furan derivatives

1.1.1. With formamide

1.1. 2. With nitrile compounds

1.1.3. With orthoethers

1.1.4. With isothiocyanates

1.1.5. With acid halide derivatives

1.1.6. With formic acid

1.1.7. With acid anhydride

1.1.8. With thiourea derivatives

1.1.9. With miscellaneous reagents

1.2. From Pyrimidine derivatives

1.2.1. From uracil and thiouracil derivatives

1.2.2. From barbituric and thiobarbituric acid derivatives

1.2.3. From other pyrimidine derivatives

1.3.References

\section{Council for Innovative Research}

Peer Review Research Publishing System

Journal: Journal of Advances in Chemistry

Vol 3, No.3

editor@cirworld.com

www.cirworld.com, member.cirworld.com 


\section{Introduction}

Furopyrimidine derivatives are an important class of heterocyclic compounds in pharmaceutical discovery research. Antifungal $^{1}$, antifolate ${ }^{2-4}$, antibacterial ${ }^{5}$, antitumor ${ }^{3}$, antiviral ${ }^{6}$, and anti-HCMV (anti-human cytomegalovirus) ${ }^{7}$ activities have been described for these compounds. Some of furopyrimidines are active on the blood circulatory system ${ }^{8}$ and can stimulate the skin preparative regeneration and increase the efficiency of the antibiotic therapy of Staphylococcus and proteus inflected wounds. ${ }^{9}$ The present review deals with description of the various synthetic routes for furopyrimidine derivatives as up till now, to our knowledge, no one study this topic in details in the literature,

\section{Discussion}

There are three fundamentals furopyrimidine system. They are Furo[2,3-d]pyrimidine (I), furo[3,2-d]pyrimidine (П) and furo[3,4-d]pyrimidine (Ш) according to the following presentation.<smiles>c1ncc2ccoc2n1</smiles>

(I)<smiles>c1ncc2occc2n1</smiles>

(II)<smiles>c1ncc2cocc2n1</smiles>

(III)

The building of furopyrimidine moiety has been achieved either by construction of pyrimidine nucleus on the parent furan ring or construction of furan nucleus on the parent pyrimidine ring.

\subsection{From Furan derivatives}

The simple approach to a new pyrimidine ring involves introducing a one-carbon fragment between two suitable and vicinal functional groups in furan rings.

\subsubsection{With formamide}

Formamide reacted with vicinal aminocyano, vicinal acylamino and vicinal aminoester furans to yield the target furopyrimidines.

Treatment of 2-amino-5-arylfuran-3-carbonitrile derivatives (1) with formamide yielded 4-amino-6-arylfuro[2,3-d]pyrimidine derivatives (2). 10

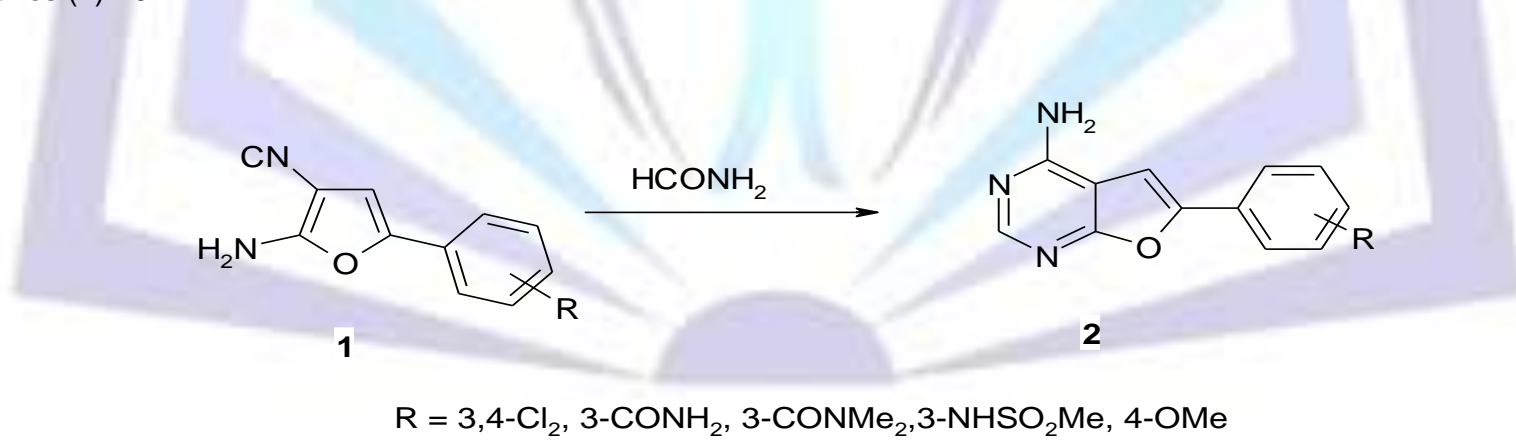

In similar manner, cyclization of 2-amino-5-substitutedfuran-3-carbonitrile derivatives (3i-v) with formamide resulted in the formation of 4-amino-6-substitutedfuro[2,3-d] pyrimidine (4i-v).11 
<smiles>N#Cc1cc(-c2ccc([Tl])cc2)oc1N</smiles>

3i-v<smiles>[R]c1ccc(-c2cc3c(N)ncnc3o2)cc1</smiles>

$4 \mathbf{i}-\mathbf{v}$

(i) $\mathrm{R}^{1}=\mathrm{OCH}_{3}$; (ii) $\mathrm{R}^{1}=\mathrm{H}$; (iii) $\mathrm{R}^{1}=\mathrm{Cl}$

(iv) $\mathrm{R}^{1}=\mathrm{CH}_{3} ;$ (v) $\mathrm{R}^{1}=\mathrm{F}$

Also, cycloaddition of 2-amino-4-arylfuran-3-carbonitrile derivatives (5) with formamide led to the corresponding 4-amino-5arylfuro[2,3-d]pyrimidine derivatives (6). 10<smiles>N#Cc1c(-c2ccccc2)coc1N</smiles>

5

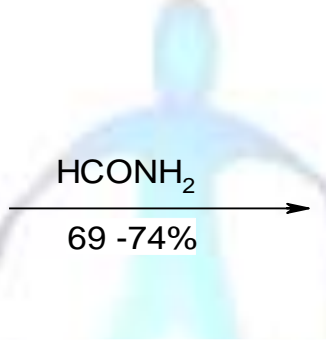

$\mathrm{R}=4-\mathrm{OMe}$, 4-NMe ${ }_{2}$, 4-phenyl and 3-NHAc<smiles>[R]c1ccc(-c2coc3ncnc(N)c23)cc1</smiles>

6

The reaction of 2-amino-4,5-diphenylfuran-3-carbonitrile (7)12 with formamide gave the corresponding 4-amino-5,6diphenylfuro[2,3-d]pyrimidine (8).13<smiles>N#Cc1c(N)oc(-c2ccccc2)c1-c1ccccc1</smiles>

7

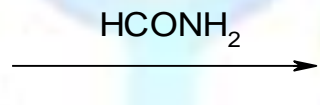

8

By analogy, the synthesis of other fused pyrimidines can be achieved by refluxing of 2-amino-4,5-dimethylfuran-3carbonitrile (9) with formamide in the presence of acetic anhydride afforded 4-amino-5,6-dimethylfuro[2,3-d]pyrimidine (10).14-16<smiles>Cc1oc(N)c(C#N)c1C</smiles>

9

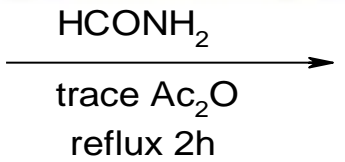

reflux $2 \mathrm{~h}$<smiles>Cc1oc2ncnc(N)c2c1C</smiles>

10

Treatment of 2-amino-4,5-disubstitutedfuran-3-carbonitrile (11a,b)with formamide yielded 4-amino-5,6disubstitutedfuro[2,3-d]pyrimidines (12a,b). 17 
<smiles>[R]c1oc(N)c(C#N)c1[R]</smiles>

$11 a, b$

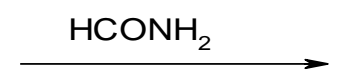
a, $R=2$-furyl
b, $R=2$-thienyl<smiles>[R]c1oc2ncnc(N)c2c1[R]</smiles>

$12 a, b$

On other hand, furopyrimidines can be obtained from reaction of vicinal acylamino furans. The 2-amino-4-bezoyl3-phenylfuran-5-carbonitrile (13) reacted with formamide to produce 4,5-diphenylfuro[2,3-d]pyrimidine-6-carbonitrile (14). 18<smiles>N#Cc1oc(N)c(C(=O)O)c1-c1ccccc1</smiles>

13

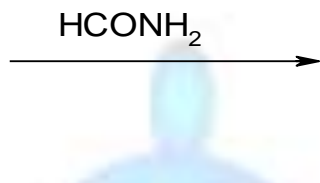

14

Also, furopyrimidines can be obtained from reaction of vicinal aminoester furans. The condensation of furan derivatives $15 a, b$ with formamide afforded the corresponding furo[2,3-d]pyrimidine derivatives 16a,b.19<smiles>CCOC(=O)c1c(N)oc(-c2cccc([N+](=O)[O-])c2)c1C(=O)OCC</smiles>

$15 \mathrm{a}, 4-\mathrm{NO}_{2}$ b, $3-\mathrm{NO}_{2}$

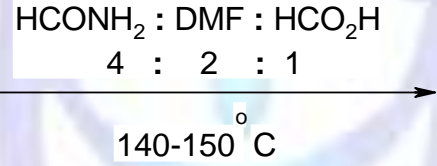

$140-150 \mathrm{C}$<smiles>N#Cc1oc2ncnc(-c3ccccc3)c2c1-c1ccccc1</smiles>

14

\subsection{With nitrile compounds}

Nitriles reacted with vicinal aminocyano and vicinal acylamino furans to yield the target furopyrimidines. Interaction of compound 7 with benzonitrile and sodium methoxide in refluxing 2-propanol afforded the corresponding 4 amino-2,5,6-triphenylfuro[2,3-d]pyrimidine (17).13<smiles>N#Cc1c(N)oc(-c2ccccc2)c1-c1ccccc1</smiles>

7<smiles>CCOC(=O)c1c(-c2ccccc2)oc2ncnc(O)c12</smiles>

16a, $4-\mathrm{NO}_{2}$ b, 3-NO<smiles>CC[N+](C)(C)OC</smiles>

Also, the effect of acetonitrile on the compound 7 afforded exclusively fused 4-aminopyrimidines 18, while chloroacetonitrile led to the formation of 4-chloropyrimidine 19. These different products can be represented as shown in the following scheme.20 


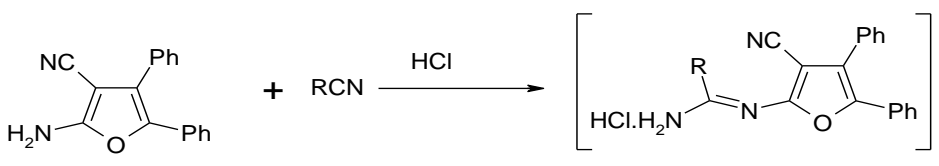

7

20

$\| \mathrm{HCl}$<smiles>[R]C(N)=Nc1oc(-c2ccccc2)c(-c2ccccc2)c1C(=N)Cl</smiles>

21

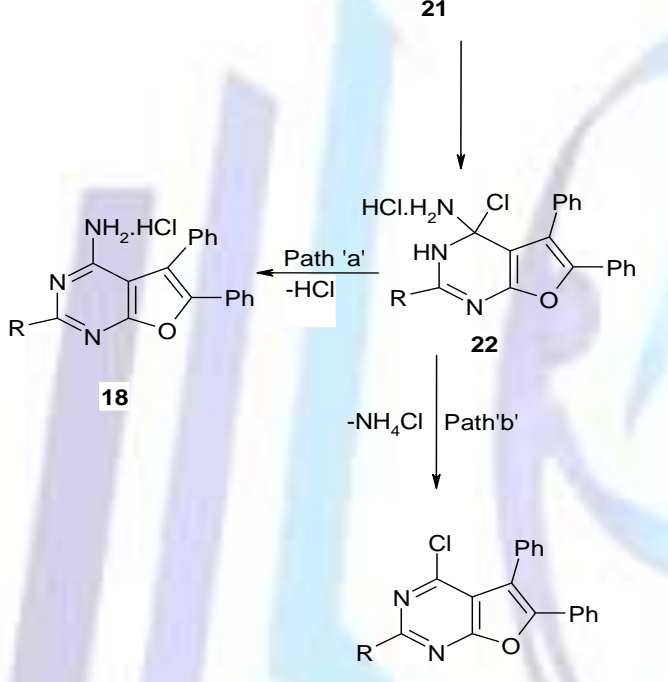

19

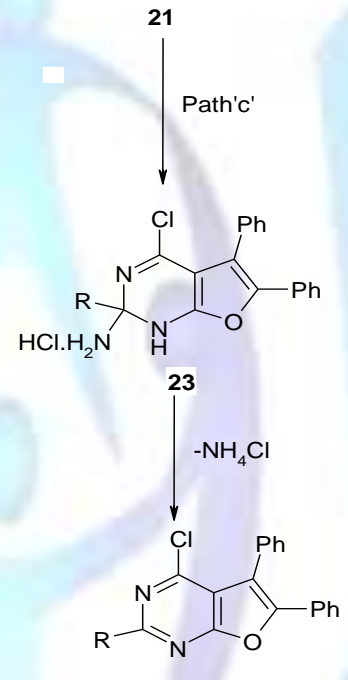

19

$\mathrm{R}=\mathrm{CH}_{3}, \mathrm{C}_{6} \mathrm{H}_{5}, \mathrm{ClCH}_{2}, \mathrm{Cl}_{2} \mathrm{CH}, \mathrm{CH}_{2} \mathrm{CO}_{2} \mathrm{C}_{2} \mathrm{H}_{5}$, $\mathrm{CO}_{2} \mathrm{C}_{2} \mathrm{H}_{5}$

On other hand, furopyrimidines can be obtained from reaction of vicinal acylamino furans. Treatment of compound 13 with malononitrile and trichloroacetonitrile gave 2-cyanomethyl-4,5-diphenylfuro[2,3-d]pyrimidine-6-carbonitrile (24) and 4,5-diphenyl-2-trichloromethylfuro[2,3-d]pyrimidine-6-carbonitrile (25), respectively.18<smiles>N#Cc1oc2nc(C(Cl)(Cl)Cl)nc(-c3ccccc3)c2c1-c1ccccc1</smiles>

25

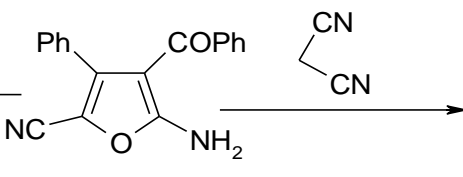

13<smiles>N#CCc1nc(-c2ccccc2)c2c(-c3ccccc3)c(C#N)oc2n1</smiles>

24 


\subsubsection{With orthoethers}

Treatment of compound 7 with triethylorthoformate (T.E.O.F) yielded ethoxymethyleneimine derivative 26 which can be cyclized by the action of ammonia gave compound 8.21<smiles>CCCc1oc(N)c(C#N)c1-c1ccccc1</smiles>

7<smiles>CCOC=IC1CCCCC1</smiles><smiles>[AlH2]</smiles><smiles>Cc1oc(-c2ccccc2)c(-c2ccccc2)c1C</smiles>

26<smiles>Nc1ncnc2oc(-c3ccccc3)c(-c3ccccc3)c12</smiles>

8

Also, 3-acetamidophenyl-2-aminofuran-3-carbonitrile (27) was treated with T.E.O.F followed by amination and cyclization in the presence of sodium ethoxide to give 5-(4-acetomidophenyl)-4-aminofuro[2,3-d]pyrimidine (28).22

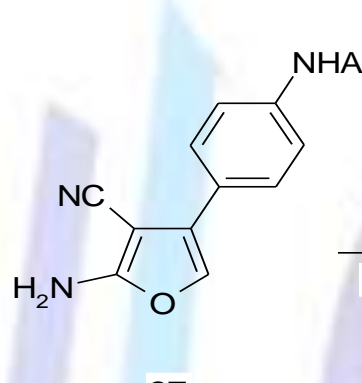

27 (i) T.E.O.F, $\mathrm{Ac}_{2} \mathrm{O}$

(ii) $\mathrm{NH}_{3}$, EtOH-THF

(iii) $\mathrm{NaOEt}$, EtOH-THF

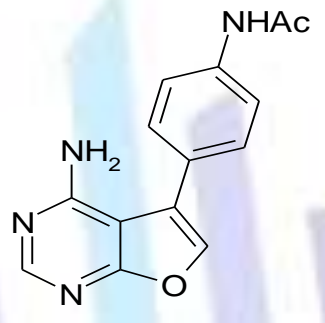

28

Similarly, treatment of 2-amino-5-(m-pyridyl)furan-3-carbonitrile (29) with diethoxymethineacetate afforded an ethoxyimino derivative, followed by reaction with ammonia in a solution of ethanol and tetrahydrofuran. Subsequently, cyclization was completed by addition of sodium ethoxide to give 4-amino-6-(m-pyridyl)furo[2,3-d] pyrimidine (30).11

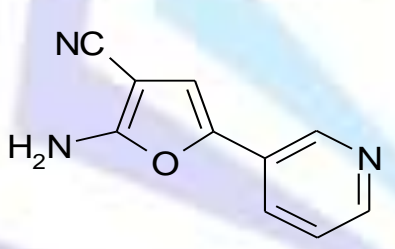

29 (i) $(\mathrm{EtO})_{2} \mathrm{CHOCOCH}_{3}, \mathrm{Ac}_{2} \mathrm{O}$

(ii) $\mathrm{NH}_{3}, \mathrm{EtOH}-\mathrm{THF}$

(iii) NaOEt, EtOH-THF

30

In addition to, 2( $\alpha$-ethoxyethylideneamino)-4,5-diphenylfuran-3-carbonitrile (31) was obtained by reaction of compound 7 with triethylorthoacetate (T.E.O.A) in refluxing acetic anhydride. Furthermore, compound 31 was stirred with hydrazine hydrate yielding 3-amino-4-imino-2-methyl-5,6-diphenyl-3H,4H-furo[2,3-d]pyrimidine (32) in good yield.23<smiles>CCOC(C)=Nc1oc(-c2ccccc2)c(-c2ccccc2)c1C#N</smiles>

7

31

32 
Also, 2-amino-4,5-di-(4-methoxyphenyl)furan-3-carbonitrile (33) reacted with T.E.O.F or T.E.O.A in acetic anhydride affording the corresponding imidates $34 a, b$. The reaction of $34 a, b$ with semicarbazide hydrochloride gave 4-imino-5,6-di(p-methoxyphenyl)-3-uriedofuro[2,3-d] pyrimidine 36a and its 2-methyl analogue 36b. The formation of compounds 36a,b were rationalized in terms of the initial formation of the intermediate 35. Also, hydrazinolysis of $34 a$ in ethanol yielded the 3-amino-4-imino-5,6-di(4-methoxyphenyl)-3H,4H-furo[2,3-d]pyrimidine (37).24

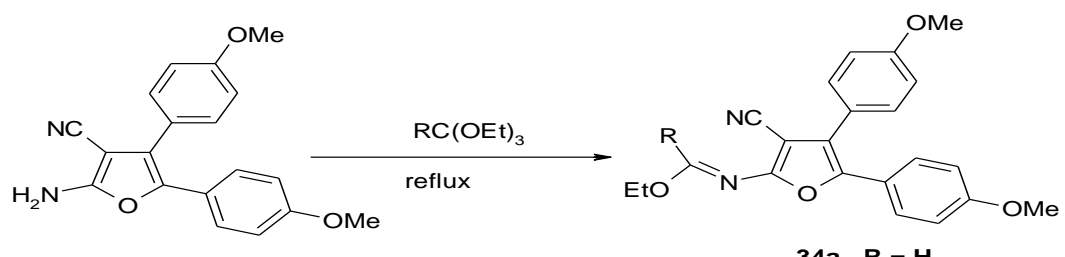

33

34a, $R=\mathbf{H}$

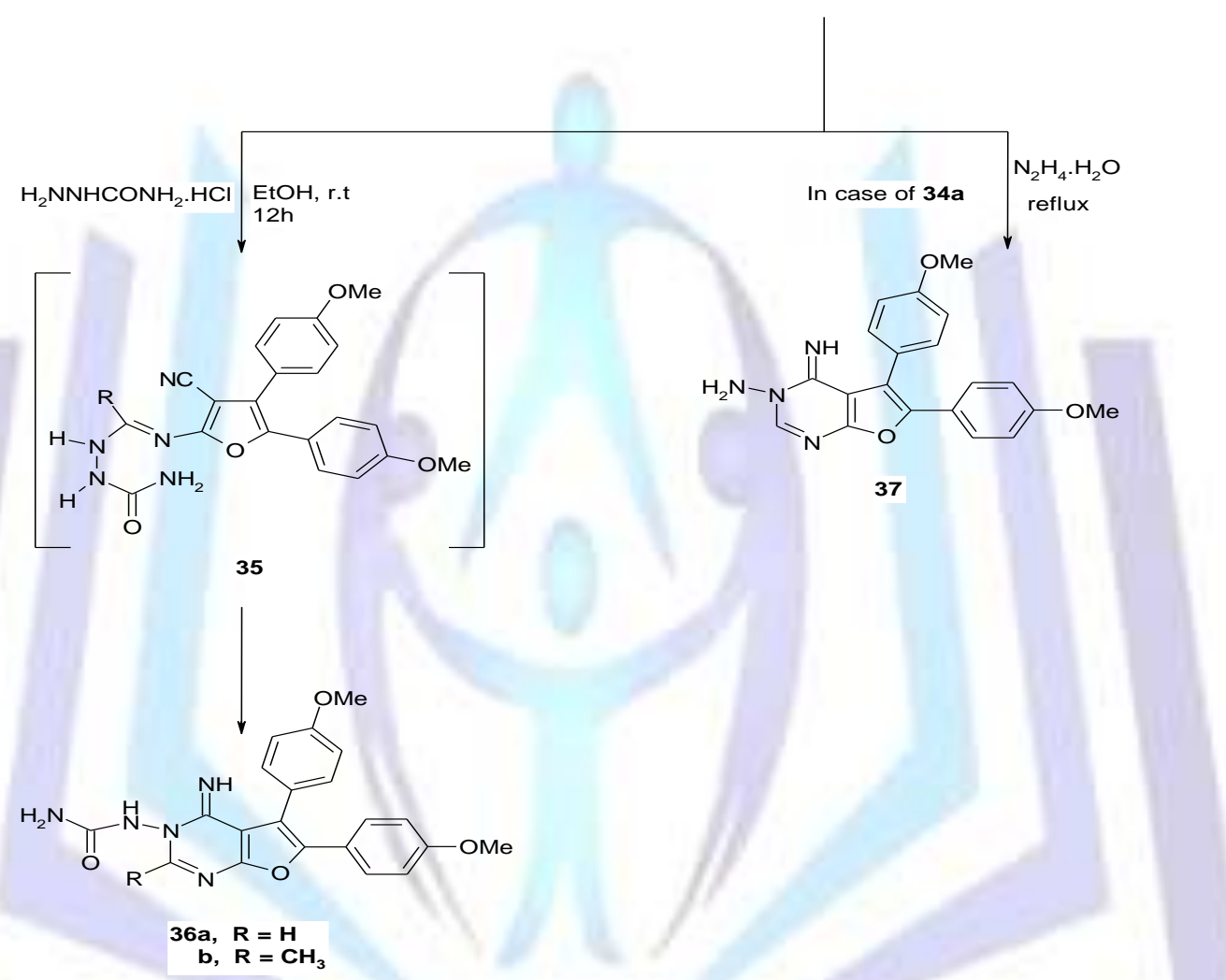

On ther hand, the imidoester 34a react with 4-hydroxybenzoylhydrazine (38) giving the amidrazone intermediate 39. Heating a solution of the amidrazone 39 produced 4-iminofuro[2,3-d]pyrimidine derivative 40.24 
<smiles>CCOC=Nc1oc(-c2ccc(OC)cc2)c(-c2ccc(OC)cc2)c1C#N</smiles>

34a

38<smiles>CCOc1ccc(-c2oc(/N=C/NNC(=O)c3ccc(O)cc3)c(C#N)c2-c2ccc(OC)cc2)cc1</smiles>

\subsubsection{With isothiocyanates}

Phenyl isothiocyanate reacted with vicinal aminocyano and vicinal acylamino furans to yield the target furopyrimidines. Treatment of compound 7 with phenylisothiocyanate at room temperature in the presence of equivalent amount of sodium hydroxide gave 4-imino-3-phenyl-5,6-diphenylfuro[2,3-d]pyrimidine-2-thione (41).25

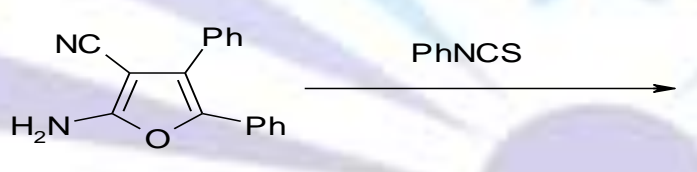

7

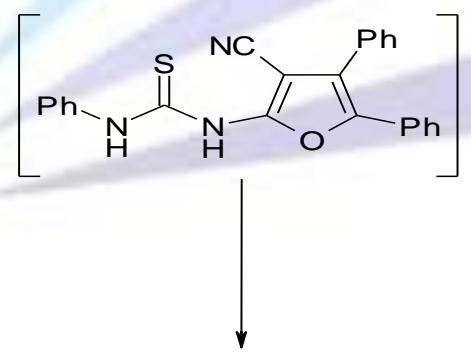<smiles>N=c1c2c(-c3ccccc3)c(-c3ccccc3)oc2[nH]c(=S)n1-c1ccccc1</smiles>

41

On other hand, furopyrimidines can be obtained from reaction of vicinal acylamino furans. Thus, cycloaddition of compound 13 with phenylisothiocyanate in dry acetone in the presence of catalytic amount of piperidine gave 2,3-dihydro2-thioxo-3,4,5-triphenylfuro[2,3-d] pyrimidine-6-carbonitrile (42).18 
<smiles>N#Cc1oc(N)c(C(=O)Nc2ccccc2)c1C(=O)Nc1oc2nc(=S)n(-c3ccccc3)c(-c3ccccc3)c2c1-c1ccccc1</smiles>

13

42

\subsubsection{With acid halide derivatives}

Reaction of compound 7 with different arenecarbonyl and alkanoyl chlorides (41a-f) under microwave irradiations (MWI) in dry media yielded 2-aryl/alkyl-5,6-diphenylfuro[2,3-d] pyrimidin-4(3H)-one (44a-f). ${ }^{26}$

Conventionally, a similar cyclization of compound 7 with acyl chlorides (43a-f) to the fused pyrimidin-4-ones (44a-f), as reported by Yamazaki et al., ${ }^{9}$ is a two-step reaction requiring absolute ethanol and dry $\mathrm{HCl}$.

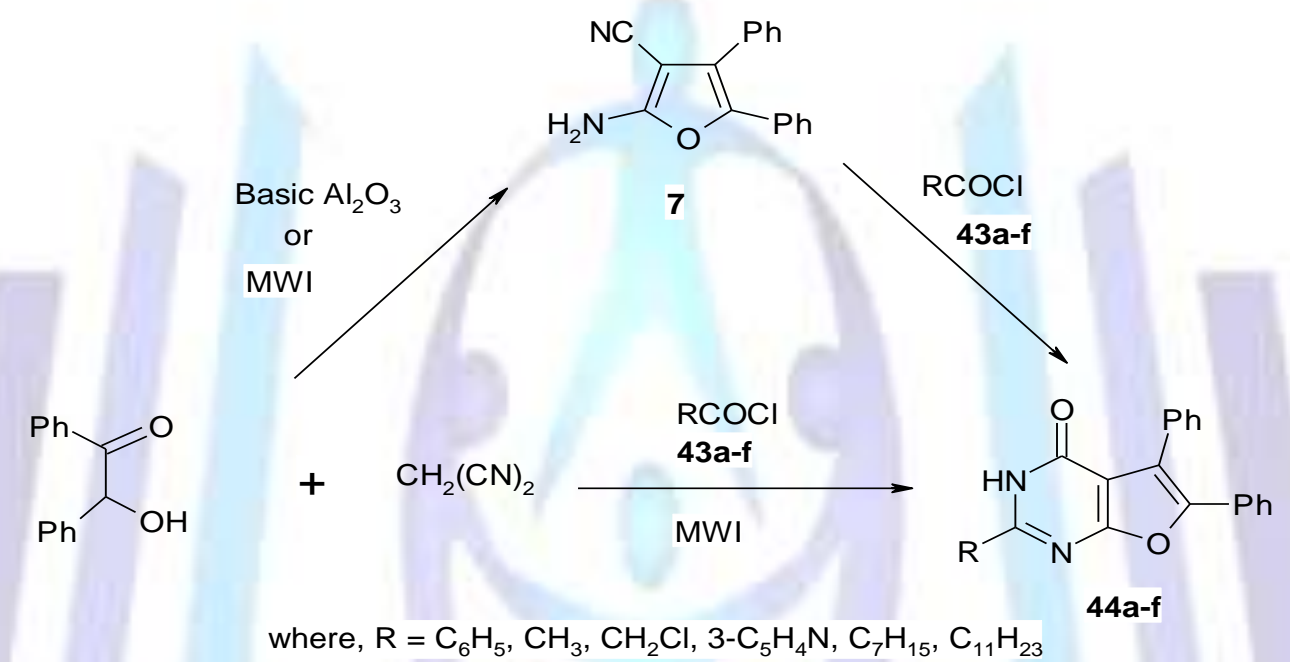

Treatment of compound 7 with chloroacetylchloride gave N-chloroacetyl derivative 45 , which underwent cyclization with potassium thiocyanate to produce the desired furo-

[2,3-d]pryimidine derivative 46.27

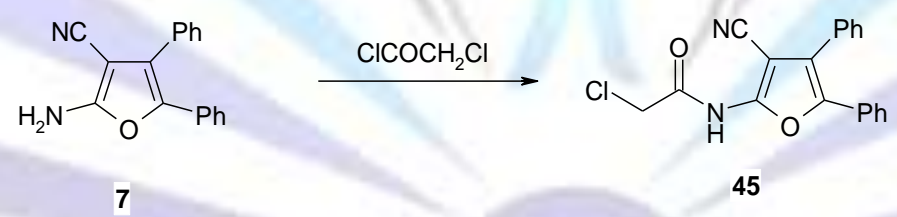

7

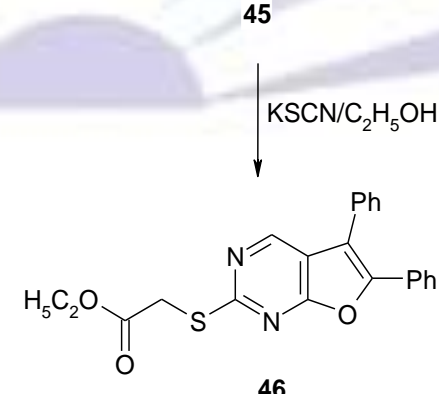

\subsubsection{With formic acid}

The action of formic acid on 2-amino-4-phenylfuran-3-carbonitrile (47) gave 5-phenylfuro[2,3-d]pyrimidin-4(3H)one (48).28 
<smiles>N#Cc1c(-c2ccccc2)coc1N</smiles>

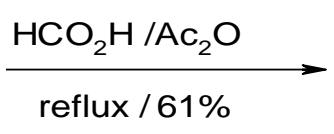<smiles>O=c1[nH]cnc2occ(-c3ccccc3)c12</smiles>

Also, compound 7 underwent cyclization with formic acid to produce 5,6-diphenylfuro[2,3-d] pyrimin-4(3H)-one (49).13<smiles>N#Cc1c(N)oc(-c2ccccc2)c1-c1ccccc1</smiles>

7

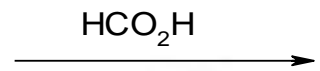

49

\subsubsection{With acid anhydride}

The reaction of 3 -furancarbonitriles $50 \mathrm{a}-\mathrm{c}$ with acid anhydrides in order to explore the scope of this type of reaction was examined. When a mixture of $50 \mathrm{a}-\mathrm{c}$, acetic (or propionic) anhydride and tin(IV) chloride was heated in 1,2dichloroethane, the corresponding 3-acylfuro[2,3-d]pyrimidines 51a-c (or 52a-c) were obtained in good yield.29

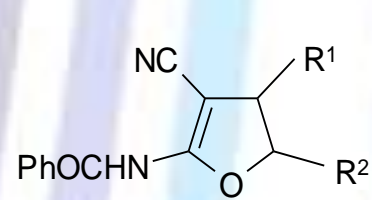

50a, $R^{1}=R^{2}=H$

b, $R^{1}=H, R^{2}=M e$

c, $\mathrm{R}^{1}=\mathrm{Ph}, \mathrm{R}^{2}=\mathrm{H}$<smiles>[R]C1Oc2nc(-c3ccccc3)n(C([R])[R])c(=O)c2C1[R]</smiles>

$51, \mathrm{R}=\mathrm{Me}$

52, $R=E t$

\subsubsection{With thiourea derivatives}

The condensation of aminofuran derivatives 53a,b and N-acetyl-N'methoxycarbonyl-s-methylthiourea (54)30 in the presence of mercury $(\Pi)$ chloride as catalyst gave the guanidine adducts $55 a, b$ which smoothly converted in sodium methoxide to the furo- $[3,2-d]$ pyrimidine derivatives $56 a, b .31$

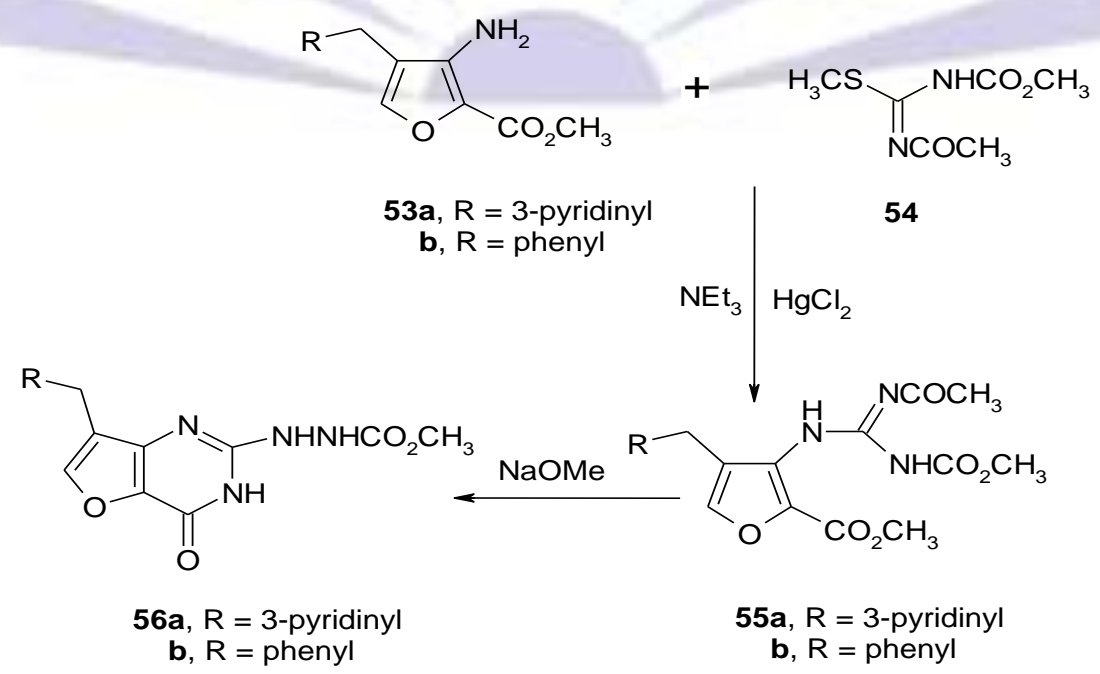




\subsubsection{With miscellaneous reagents}

The action of phosgene iminium chloride on the compound 7 in 1,2-dichloroethane was explained by the formation of 4-chloro-2-dimethylamino-5,6-diphenylfuro[2,3-d]pyrimidine (57).32<smiles>CN(C)c1nc(Cl)c2c(-c3ccccc3)c(-c3ccccc3)oc2n1</smiles>

On the other hand, furo[2,3-d]pyrimidines 60 are prepared via stepwise cyclization reaction of 2-aminofurans 58 involving an inverse electron demand Diels-Alder (IDA) reaction, followed by the elimination of ammonia, and a final retro Diels-Alder reaction.33

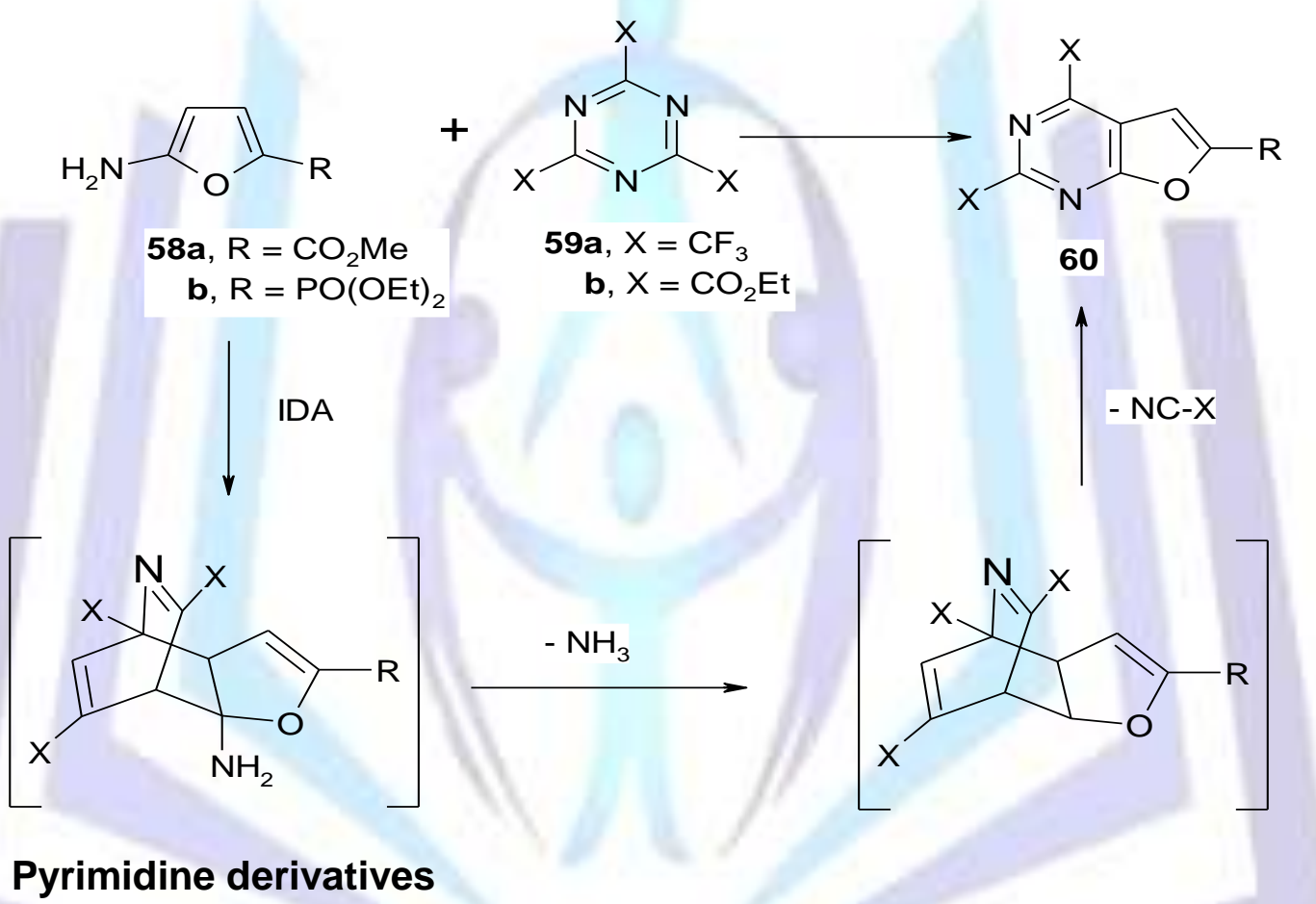

\subsection{From Pyrimidine derivatives}

The location of the ring oxygen in furo[2,3-d]pyrimidines suggests that pyrimidines bearing an oxygen at C-6 would serve as good candidates for developing the furan ring. On the other hand, pyrimidines with an oxygen function at $\mathrm{C}-5$ represent the most efficient precursors to furo[3,2-d]pyrimidines. Furthermore, virtually all of the syntheses methods lead to an oxidized form of the furan ring.

\subsubsection{From uracil and thiouracil derivatives}

Uracils represent important starting materials which cooperate in construction of the target furopyrimidines. There are many derivatives of uracils which served in formation furopyrimidines like halogenated, alkynyl, amino and hydroxy uracils.

The coupling reaction of halogenated pyrimidinone derivatives 61a-c34 with propargyl alcohol (62) gave the expected alkynyl derivatives 63a-c, which could neither be isolated nor detected and furo[2,3-d]pyrimidine derivatives 64a-c were obtained in moderate yields. 35 


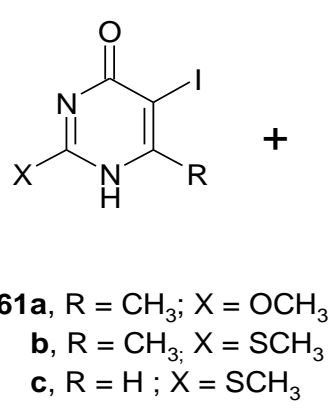<smiles>[X]c1nc(=O)c(C#CCO)c([R])[nH]1</smiles>

63a-c<smiles>[X]c1nc([R])c2cc(CO)oc2n1</smiles>

Similarly, reaction of 5 -iodopyrimidine derivatives 65 with alkynes $66 \mathrm{a}, \mathrm{b}$ in acetonitrile afforded the corresponding furo[2,3-d]pyrimidines 67a,b.36<smiles>CC(=O)OC1C(=O)OC2C3CC(C3OC(C)=O)C12</smiles>

65

$$
+\quad \int_{\mathrm{CH}}^{\mathrm{R}} \stackrel{\text { i) Pd-catalyzed or }}{\stackrel{\begin{array}{c}
\text { ii) } 10 \% \mathrm{Pd} / \mathrm{C} \text {, reflux } \\
\text { Cul, acetonitrile }
\end{array}}{\longrightarrow}}
$$

$\mathrm{BzOCH}_{2}$

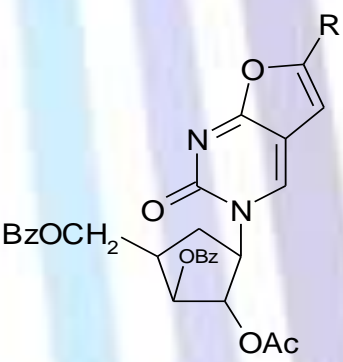

67a, $\mathrm{R}=\mathrm{Ph}$

b, $\mathrm{R}=\mathrm{CH}_{2} \mathrm{OH}$

Also, treatment of 5-iodo-2 -deoxyuridine (68) and alkynyl derivatives 69a-d gave the intermediate 5-alkynyl nucleosides, which can be cyclized in situ with copper(I) iodide to give 3-(2-deoxy- $\beta$-D-ribofurosyl)-6-substituted-2,3-dihydrofuro[2,3d]pyrimidin-2-ones (70a-d) in moderate yields.37

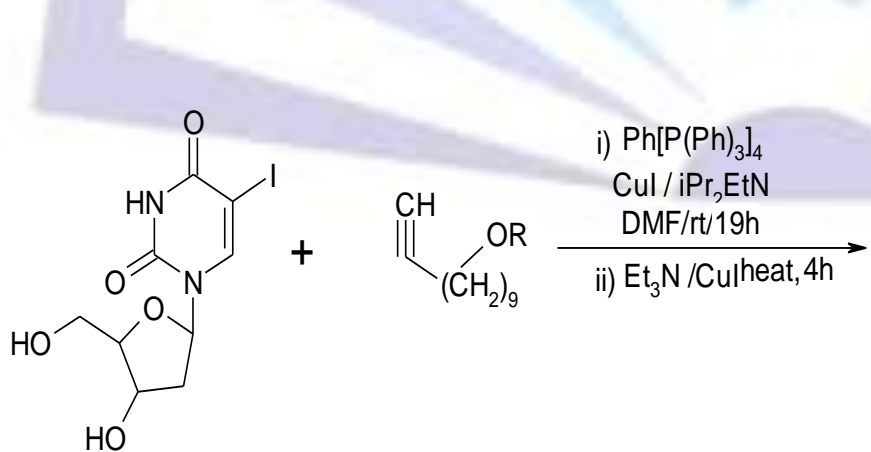

68

$$
\begin{aligned}
\text { 69a, } \mathrm{R} & =\mathrm{C}_{4} \mathrm{H}_{9} \\
\text { b, } \mathrm{R} & =\mathrm{C}_{5} \mathrm{H}_{11} \\
\text { c, } \mathrm{R} & =\left(\mathrm{CH}_{2}\right) \mathrm{ipr} \\
\text { d, } \mathrm{R} & =\left(\mathrm{CH}_{2}\right) \mathrm{Cl}
\end{aligned}
$$

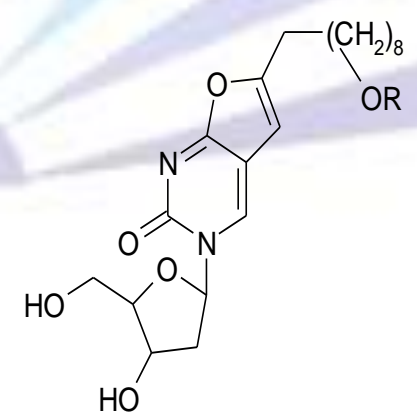
70a, $\mathrm{R}=\mathrm{C}_{4} \mathrm{H}_{9}$
b, $\mathrm{R}=\mathrm{C}_{5} \mathrm{H}_{11}$
c, $\mathrm{R}=\left(\mathrm{CH}_{2}\right)$ ipr
d, $\mathrm{R}=\left(\mathrm{CH}_{2}\right) \mathrm{Cl}$ 
On the other hand, 5-ethynyl-2-deoxyuridine (71) was coupled with p-alkylaryliodides $72 a-h$ to achieve the corresponding 5-arylethynyl-2 -deoxyuridines (73a-h), which cyclized in the presence of copper-catalysed to form the corresponding furo[2,3-d]pyrimidine ring derivatives (74a-h).38<smiles></smiles>

71<smiles>[R]c1ccc(I)cc1</smiles>

73a-h

72a-h

$$
\begin{aligned}
\mathbf{R}= & \mathrm{CH}\left(\mathrm{CH}_{3}\right)_{2}, \mathrm{CH}_{2} \mathrm{CH}\left(\mathrm{CH}_{3}\right)_{2}, \mathrm{CH}_{2} \mathrm{CH}_{2} \mathrm{CH}\left(\mathrm{CH}_{3}\right)_{2}, \\
& \mathrm{CH}_{2} \mathrm{CH}_{2} \mathrm{CH}_{2} \mathrm{CH}\left(\mathrm{CH}_{3}\right)_{2}, \mathrm{C}\left(\mathrm{CH}_{3}\right)_{3}, \mathrm{CH}_{2} \mathrm{C}\left(\mathrm{CH}_{3}\right)_{3}, \\
& \mathrm{CH}_{2} \mathrm{CH}_{2} \mathrm{C}\left(\mathrm{CH}_{3}\right)_{3}, \mathrm{C}_{6} \mathrm{H}_{11}
\end{aligned}
$$

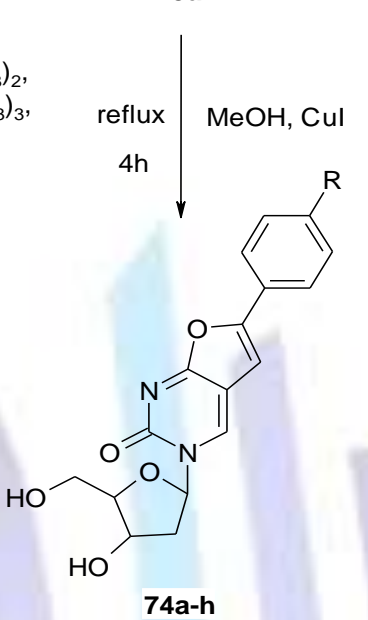

By similar manner, 5-Alkynylpyrimidines 75 were reacted with copper (I) iodide in the presence of triethylamine to afford furo[2,3-d]pyrimidine derivatives 76.39

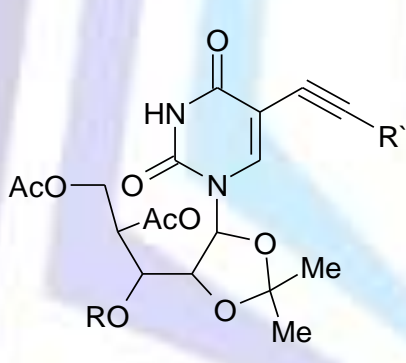

75

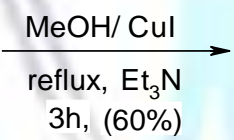

$3 \mathrm{~h},(60 \%)$

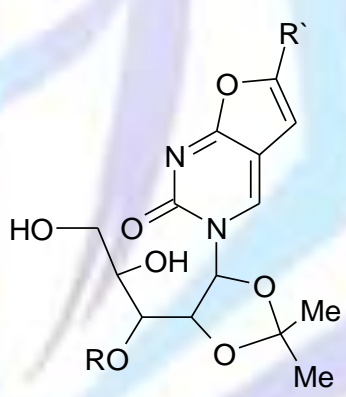

76

$$
\begin{aligned}
& \mathbf{R}=\mathrm{CH}_{3}, \mathrm{PhCH}_{2}, \mathrm{C}_{3} \mathrm{H}_{5} \\
& \mathbf{R}^{\prime}=\mathrm{C}_{7} \mathrm{H}_{15}, \mathrm{C}_{10} \mathrm{H}_{21}
\end{aligned}
$$

Also, Starting from protected C5-alkynyl acyclic nucleosides 1-N-(2-acetoxyethoxymethyl)-5-substituteduracils (77a-d) in acetone with silver nitrate, the desired 3-N-(2-acetoxyethoxymethyl)-2,3-dihydro-6-substitutedfuro[2,3-d]pyrimidin-2-ones (78a-d) were obtained.40<smiles>C#Cc1cn(COCCOC(C)=O)c(=O)[nH]c1=O</smiles>

77

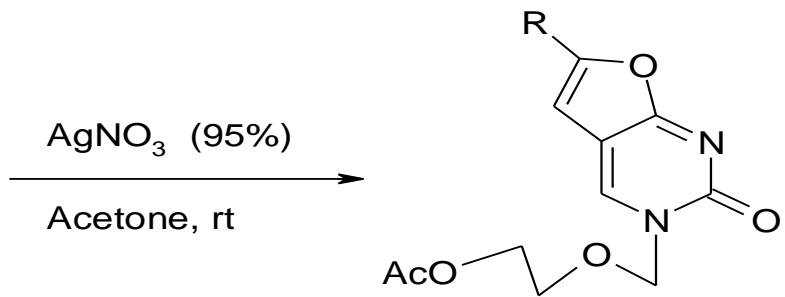

78

a, $\mathrm{R}=\mathrm{C}_{8} \mathrm{H}_{17} ; \mathbf{b}, \mathrm{R}=\mathrm{PhC}_{5} \mathrm{H}_{11} ; \mathbf{c}, \mathrm{R}=\mathrm{Ph} ; \mathbf{d}, \mathrm{R}=\mathrm{C}_{5} \mathrm{H}_{11}$ 
On the other hand, 4-aminopyrimidine derivative 79 reacted with $\alpha$-bromoacetone (80) in dimethylether (DME) to obtain the corresponding furo[2,3-d]pyrimidine derivative 81.41<smiles>CCSc1nc(N)cc(O)n1</smiles>

79<smiles>CC(=O)CBr</smiles>

80<smiles>CC[AsH2]c1nc(N)c2c(C)coc2n1</smiles>

81

The furo[2,3-d]pyrimidin-2(3H)-one (83) can be synthesized via the cyclization of bromovinyldeoxyuracil (82) by using potassium tert-butylate as a base, whereas less bulkier bases led to decomposition of the reaction mixture.42<smiles>O=c1[nH]cc(/C=C/Br)c(=O)[nH]1</smiles>

82

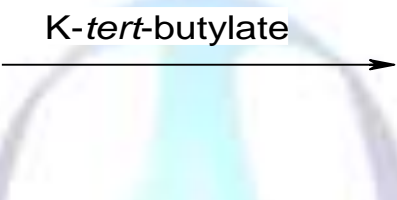

Also, the 5-acylatedthiouracil derivatives 84 undergo cyclization to 4-(substituted) aminofuro[2,3-d]pyrimidine 85.43<smiles>CSc1nc(N)c(C(=O)CCl)c(O)n1</smiles>

\section{Cyclization}<smiles>O=c1nc2occc2c[nH]1</smiles>

83

84

$$
\begin{aligned}
\mathrm{R}= & \text { tetra-O-acetyl-1/2-D-glucopyranosyl, } \\
& \text { tri- } O \text {-acetyl-2-D-xylopyranosyl }
\end{aligned}
$$

In addition to, furo[3,2-d]pyrimidine derivatives 87 can be obtained by cyclization of 5-propynyloxypyrimidines 86 in dimethylsulphoxide (DMSO) as solvent.44<smiles>[R]C#CCOc1cn(C)c(=O)n(C)c1=O</smiles>

86
(1) $\mathrm{CH}_{3} \mathrm{ONa} / \mathrm{DMSO}$

(2) Thermal cyclization / DMSO<smiles>[R]c1oc2c(=O)n(C)c(=O)n(C)c2c1[R]</smiles>

87

(1) $R=H, M e ; R^{1}=H$

(2) $R=R^{1}=M e$ 
Also, the cyclocondesation of 5-(2-methylsulfonyloxyethyl)uracil (88) in the presence of 1,8-diazbicyclo[5.4.0]undec-7-ene (DBU) as a base gave 5,6-dihydrofuro[2,3-d] pyrimidin-2(3H)-one (89).42<smiles>CO[Sb](C)(O)C(F)(F)F</smiles>

88<smiles>O=c1nc2c(c[nH]1)CCO2</smiles>

89

The reaction of 5-(2-hydroxyethyl)-6-methyl-2-thiouracil (90a) or 5-(2-hydroxyethyl)-6-methyl-2-methylthiopyrimidin$4(3 \mathrm{H})$-one $(90 \mathrm{~b})$ with thionyl chloride followed by sodium carbonate treatment led to formation of 5,6-dihydro-4-methyl-2thiofuro[2,3-d] pyrimidine (91a) or its 2-methyl analogue (91b), respectively.45<smiles>[R5]c1nc(C)c(CCO)c(=O)[nH]1</smiles>

90a, $\mathrm{R}=\mathrm{H}$

b, $\mathrm{R}=\mathrm{CH}_{3}$ i) $\mathrm{SOCl}_{2}$

ii) $\mathrm{Na}_{2} \mathrm{CO}_{3}$
$\mathrm{RS}$<smiles>[R5]c1nc(C)c2c(n1)OCC2</smiles>

In different manner, 6-allyl-5-hydroxy-1,3-dimethylpyrimidine (92) was cyclized in the presence of benzoyl peroxide into 1,3,6-trimethylfuro [2,3-d]pyrimidin-2,4(1H,3H)-dione (93) via radical cyclization type.46<smiles>C=CCc1c(O)c(=O)n(C)c(=O)n1C</smiles>

Pyrimidin-4,6-diol (94) represented isomer of uracil, which can also be used for synthesis of the target furopyrimidines. The reaction of 94 with Z-(2-chloro-2-nitroethenyl)benzene (95), which resulted from condensation of benzaldehyde and chloro(nitro)methane, with the aid of DBU afforded compound $48.47,48$

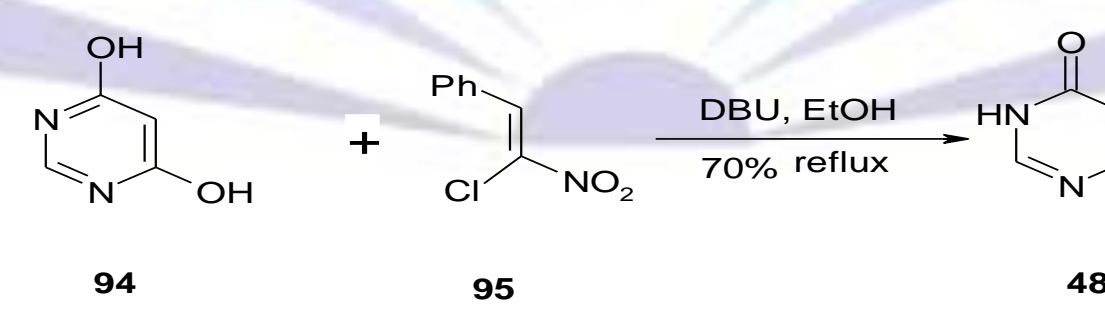

\subsubsection{From barbituric and thiobarbituric acid derivatives} applications.

Barbituric acid and thiobarituric acids were used as starting materials in formation of target furopyimidines in wide

Alkylation of 1,3-dimethylbarbituric acid (96) under phase-transfer conditions with 3-chloro-3-methylbut-1-yne (97) is also followed by cyclization to form the corresponding furo[2,3-d] pyrimidine derivative 98. 49 
<smiles>C=CC(C)(Cl)C=CC(=O)OCc1ccccc1</smiles>

Similarly, reaction of compound 96 with 1,1-diphenylethene (99) in warm acetic acid and manganese( $\Pi)$ acetate as catalyst afforded 5-hydro-1,3-dimethyl-5,6-diphenylfuro[2,3-d]pyrimidin-2,4-(1H,3H)-dione (100).50<smiles>CN1C(=O)CC(=O)N(C)C1=O</smiles>

96<smiles>C=C(Pc1ccccc1)c1ccccc1</smiles>

99<smiles>CN1C(=O)C2CC(c3ccccc3)(c3ccccc3)OC2N1C</smiles>

100

Barbiturylbenzylidenes, which prepared by Perkin condensation of aromatic aldehydes with compound 96, react with phenylisocyanide to yield 5-aryl-6-phenylamino-1,3-dimethylfuro[2,3-d]pyrimidin-2,4-(1H,3H)-diones (101).51

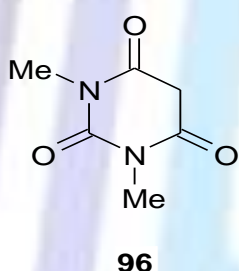

96

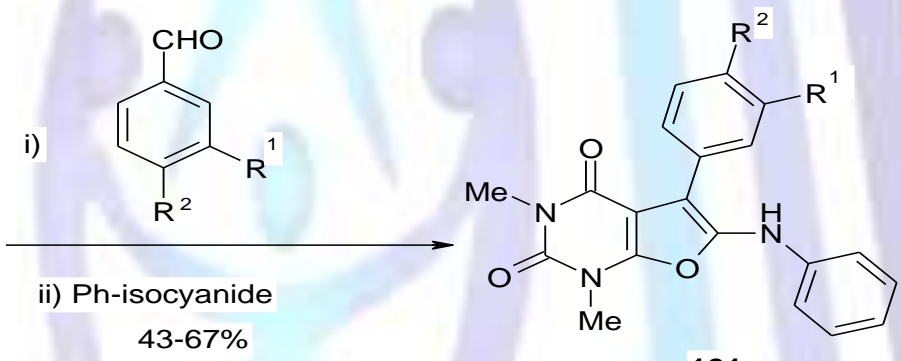

101

$\mathrm{R}^{1}=\mathrm{H}, \mathrm{R}^{2}=\mathrm{OMe}, \mathrm{R}^{1} \mathrm{R}^{2}=\mathrm{OCH}_{2} \mathrm{O}$

On the other hand, treatment of 1,3-diaryl-2-thiobarbituric acid (102) with benzoin (103) in the presence of a catalytic amount of p-toluenesulphonic acid gave the corresponding furo[2,3-d] pyrimidines 104.52<smiles>[R]N1C(=O)CC(=O)N([R])C1=S</smiles>

102<smiles>O=C(c1ccccc1)C(O)c1ccccc1</smiles>

103<smiles>[R]N1C(=O)C2C(c3ccccc3)=C(c3ccccc3)OC2N([R])C1=S</smiles>

104

$\mathrm{R}=\mathrm{H}, \mathrm{Ph}, \mathrm{C}_{6} \mathrm{H}_{4} \mathrm{Me}-o, \mathrm{C}_{6} \mathrm{H}_{4} \mathrm{Me}-m, \mathrm{C}_{6} \mathrm{H}_{4} \mathrm{Me}-p$,

$\mathrm{C}_{6} \mathrm{H}_{4} \mathrm{Cl}-p, \mathrm{C}_{6} \mathrm{H}_{4} \mathrm{OMe}-p$ 
Also, acylation of compound 102 with chloroacetyl chloride (105) in the presence of triethylamine gave 5-chloroacetyl derivative 106, which on cyclization with ethanolic sodium acetate gave the 5-oxo derivatives 107.53

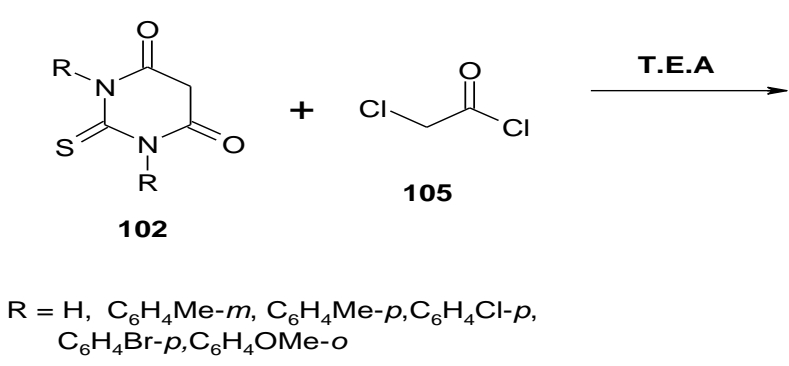<smiles>[R]N1C(=O)C(C(=O)CCl)C(=O)N([R6])C1=S</smiles><smiles>[R]n1c(=O)c2c(n([2H])c1=S)OCC2=O</smiles>

On the other hand, treatment of 5-chloroacetyl-1,3-dimethylbarbituric acid (108a) or 5-chloroacetyl-1,3-diethyl-2thiobarbituric acid $(108 \mathrm{~b})$ with triethylamine resulted in cyclization and gave 1,3-dimethylfuro[2,3-d]pyrimidine2,4,5(1H,3H,6H)-trione (109a) and 1,3-dimethylfuro[2,3-d]pyrimidine-2(1H)-thione-4,5(3H,6H)-dione (109b) respectively.54<smiles></smiles>

$$
108 \mathrm{a}, X=O, R=M e
$$

b, $X=S, R=E t$

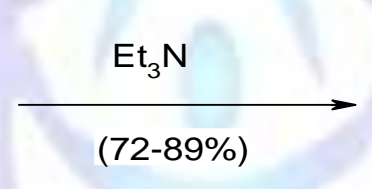<smiles></smiles>

109a, $X=O, R=M e$ b, $X=S, R=E t$

Similarly, the reaction can be started with 5,5-disubstituted barbituric acid derivatives in which one of the substituents possesses some reactive group. Thus, O-alkylation occurs in the presence of a dibromo substitent, such as observed with barbituric acid derivative 110. The furo[2,3-d]pyrimidine derivative 111 resulted from displacement of the terminal bromine by an oxy anion.55<smiles>CCCC(C(=O)NC(=O)NC)(C(Br)Br)C(C)CBr</smiles>

110

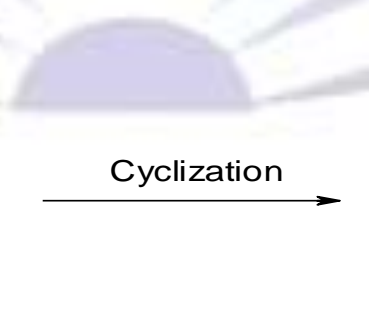<smiles>CCCC(C)C12C(=O)NC(=O)N=C1OCC2Br</smiles>

111

\subsubsection{From other pyrimidine derivatives}

There are many of other pyrimidines which be also used in construction of target furopyrimidines. The most examples, used for this purpose, were aminopyrimidine, halogenated and alkynyl pyrimidines.

The cyclocondensation of 2,6-diamino-3(H)-4-oxo-pyrimidine (112) and chloroacetone (113a) or methyl 4-(3-chloro-2oxopropyl)benzoate (113b) gave both 2-amino-4-oxo-6-substituted pyrrolo[2,3-d]pyrimidine (114a,b) and 2,4-diamino-5substitutedfuro[2,3-d] pyrimidine $(115 \mathrm{a}, \mathrm{b})$ in a $2: 1$ ratio. The yield of $115 \mathrm{a}$ by this reported method was $20 \%, 56$ while by careful protection of the reaction from light and moisture, the yield was increased to $25 \% .57,58$ 
<smiles>Nc1cc(=O)[nH]c(N)n1</smiles>

112<smiles>[R]CC(=O)CCl</smiles>

113a, $R=H$

b, $\mathrm{R}=\mathrm{C}_{6} \mathrm{H}_{4} \mathrm{COOCH}_{3}-p$<smiles>Nc1nc2[nH]c(C=P)cc2c(=O)[nH]1</smiles>

114a,b<smiles>[R]Cc1coc2nc(N)nc([NH3+])c12</smiles>

Also, the condensation of compound 112 and 1,3-dichloroacetone (116) in DME at room temperature afforded 2,4diamino-5-(chloromethyl)furo[2,3-d]pyrimidine (117).59,60
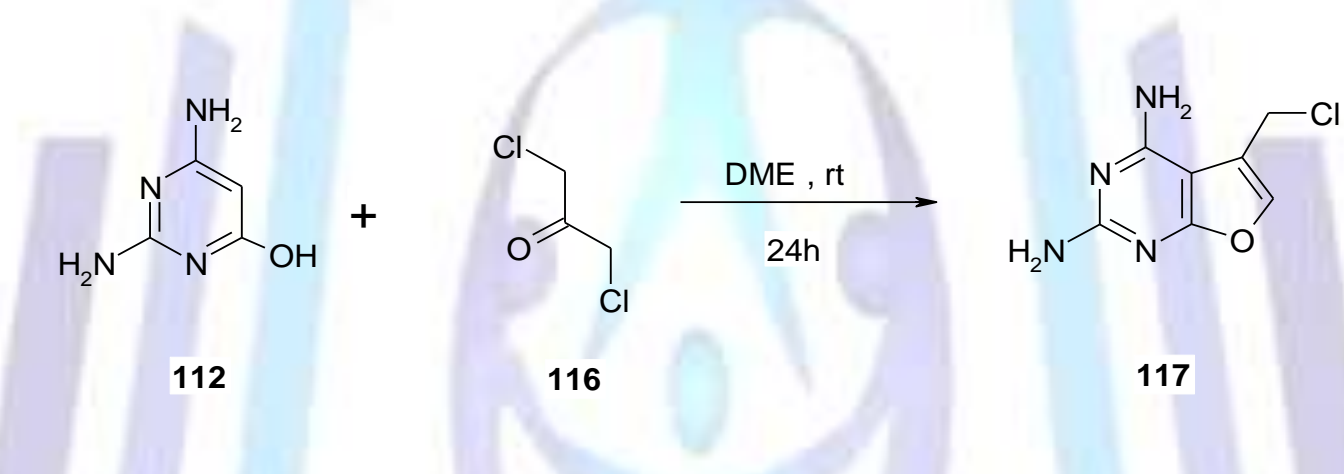

Similarly, treatment of compound 112 with methylformylchloroacetate (118) in DMSO gave a mixture of pyrrolo[2,3d]pyrimidine derivative 119 and furo[2,3-d]pyrimidine derivative 120.61
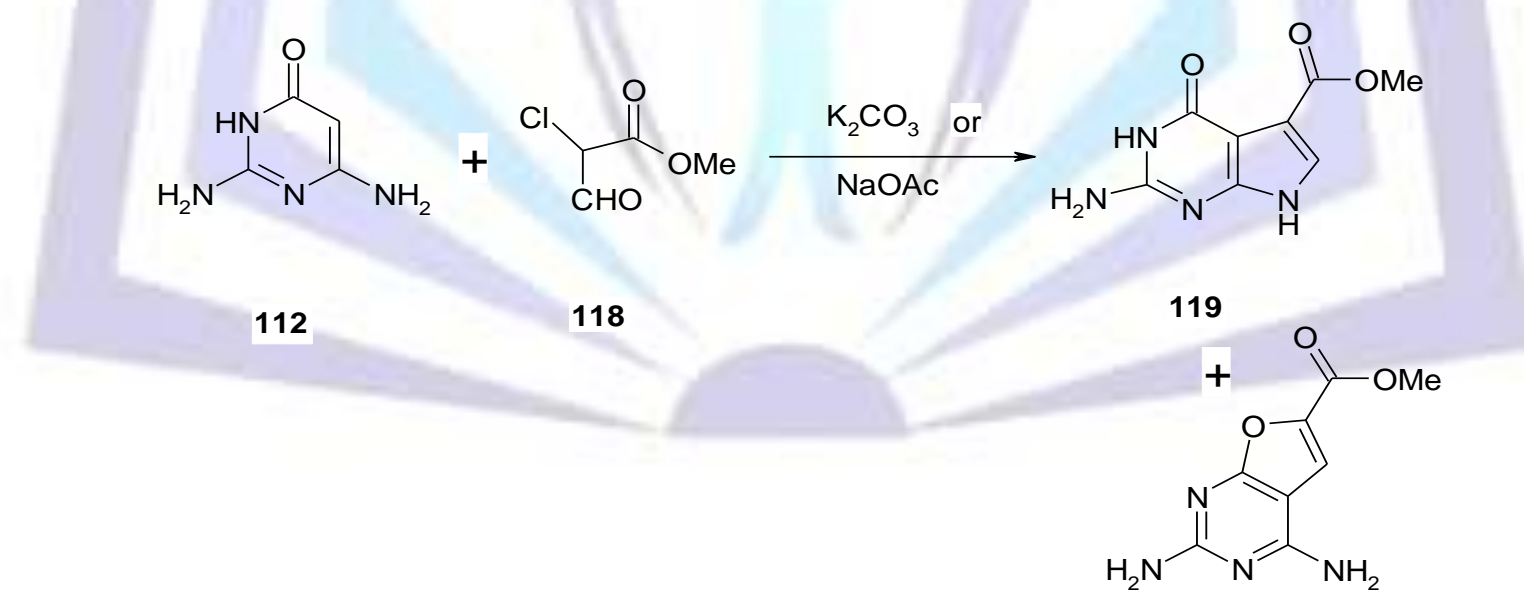

120

In addition to that, 6-amino-2-phenylpyrimidin-4(3H)-one (121) was reacted with the o-(2,4-dinitrophenyl)oxime of chloroacetone (122), which prepared by condensation of 2,4-dinitrophenol and chloroacetone oxime, in one molar amount of sodium or potassium iodide at $120^{\circ} \mathrm{C}$ to afford 4-amino-6-(2-hydroxy-3,5-dinitrophenyl)-5-methyl-2-phenylfuro[2,3-d] pyrimidine (124). The first step in the formation of 124 involves reaction of pyrimidine 121 as a nucleophile at its oxygen with the chlorooxime 122 to give compound 123. This latter is converted into furo[2,3-d]pyrimidine derivative 124 by a tautomeric double bond shift, followed by a $[3,3]$ sigmatropic rearrangement, intramolecular cyclisation onto the nucleophilic pyrimidine 5-position, and final loss of ammonia. Other structures isomeric with 124 may be drawn which fit the spectroscopic data, for example structure 125.62,63 
<smiles>[NH3+]c1cc(=O)[nH]c(-c2ccccc2)n1</smiles>

121<smiles>C/C(CCl)=N/Oc1ccc([N+](=O)[O-])cc1[N+](=O)[O-]</smiles>

122<smiles>CO[N+](=O)c1ccc(O/C=N\Oc2cc(N)nc(-c3ccccc3)n2)c([N+](=O)[O-])c1</smiles>

123<smiles>Cc1ccnc2c1OC(c1cc([N+](=O)[O-])cc([N+](=O)[O-])c1O)c1cnc(-c3ccccc3)nc1O2</smiles>

124<smiles>CN=C(C)C(Oc1cc(C)nc(-c2ccccc2)n1)c1cc([N+](=O)[O-])cc(N)n1</smiles><smiles>Cc1oc2nc(-c3ccccc3)nc(N)c2c1-c1cc([N+](=O)[O-])cc([N+](=O)[O-])c1</smiles>

125

On the other hand, pyrimidine-5-carboxylic acid 126 with thionyl chloride is postulated to involve the intermediate 127 which cyclized to form the furo[3,4-d]pyrimidine derivative 128. Evidence is presented to support the location of the sulfur and, hence, the role of the intermediate 127.64<smiles>Cc1nc(-c2ccccc2)nc(N)c1C(=O)O</smiles><smiles>O=C(Cl)C1C(NP)=NC(c2ccccc2)=NC1C(O)=S</smiles>

127

cyclization<smiles>O=C1OC(=S)c2c(Nc3ccccc3)nc(-c3ccccc3)nc21</smiles>

128 
Also, treatment of 4,5-bis(bromoethyl)-2-(methylthio) pyrimidine (129) with DMSO afforded 6-formyl derivative 130a which suggested to exist in an equilibrium with hemiacetal furo[3,4-d] pyrimidine derivative $130 \mathrm{~b} .65$<smiles>CSc1ncc(CBr)c(C=O)n1</smiles>

129

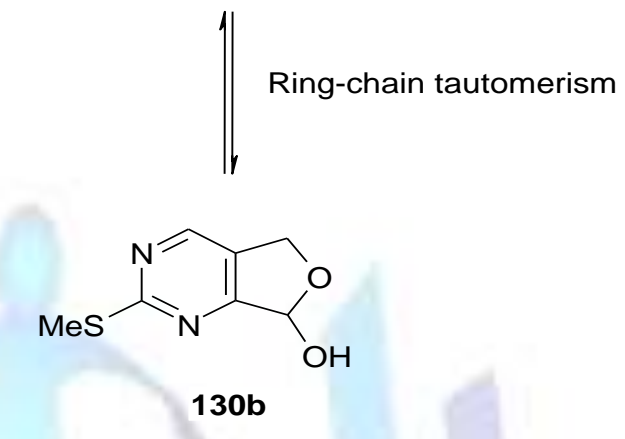

Similarly, 6-bromomethylpyrimidine derivative 131 was heated to produce the furo[3,4-d] pyrimidine derivative 132 in quantitative yield.66

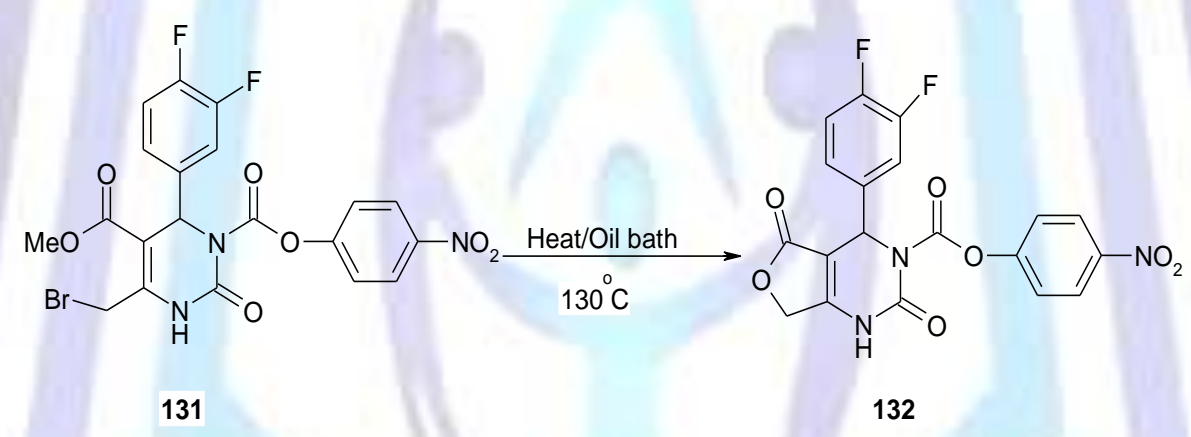

In the same way, heating of the ester derivatives 133 above $210^{\circ} \mathrm{C}$ provided the 5 -oxofuro[3,4-d] pyrimidines 134.67

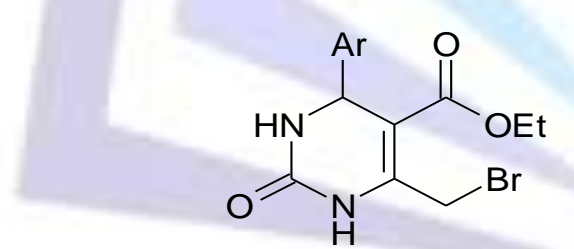

133

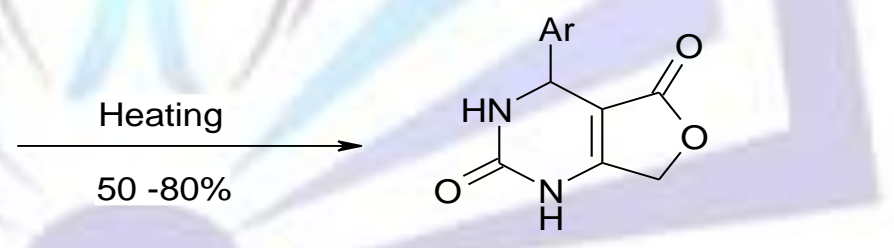

134

$$
\mathrm{Ar}=\mathrm{Ph}, \mathrm{C}_{6} \mathrm{H}_{4} \mathrm{OMe}-p, \mathrm{C}_{6} \mathrm{H}_{4} \mathrm{OH}-p, 2 \text {-furyl }
$$

Also, alkynyl pyrimidines were used to form furopyrimidines by cyclocondesation reaction. Thus, heating a solution of 2 methylthio-4-morpholino-6-phenyl ethynylpyrimidine-5-carbaldehyde (135a) in the presence of bases, the regioselective formation of (7Z)-7-benzylidene-5-methoxy-4-morpholino-5,7-dihydrofuro[3,4-d] pyrimidine (136a) took place.68

Reaction proceeded smoothly and provided high yields of 138a when 1 equiv. of sodium or potassium methoxide were used. However, the reaction of 135a with methanol in the presence of $\mathrm{PdCl} 2(\mathrm{PPh} 3) 2, \mathrm{AgNO} 3$ or CF3CO2Ag proceeded with poor regioselectivity and the formation of mixtures of $136 \mathrm{a}$ and 5-methoxy-2-methylthio-4-morpholin-4-yl-7-phenyl-5Hpyrano[4,3-d] pyrimidine (137a) was observed in these cases.69 
<smiles>[R]c1nc(S(C)(=O)=O)nc(C=Cc2ccccc2)c1C=O</smiles>

$137 a, b$

Also, cyclization of 2,6-dimethyl-5-(2-p-tolylethynyl)primidin-4-ol (138) with iodothiophene (139a) furnished 2,4-dimethyl5-(thiophen-2-yl)-6-p-tolylfuro[2,3-d] pyrimidine (140a).70

On the other hand, the reaction of 138 and iodobenzene (139b) were annulated by palladium-catalyzed cyclization to give the furo[2,3-d]pyrimidine derivatives $140 \mathrm{~b}$ in $33 \%$ yield accompanied with the directly cyclized by product 141.47 While, when cesium carbonate was used as soft base, the yield of $140 \mathrm{~b}$ increased to $57 \%$ as the major product.46As the same as, treatment of 138 with sterically hindered 2-iodotoluene (139c) produced the furo[2,3-d] pyrimidine derivative 141.70

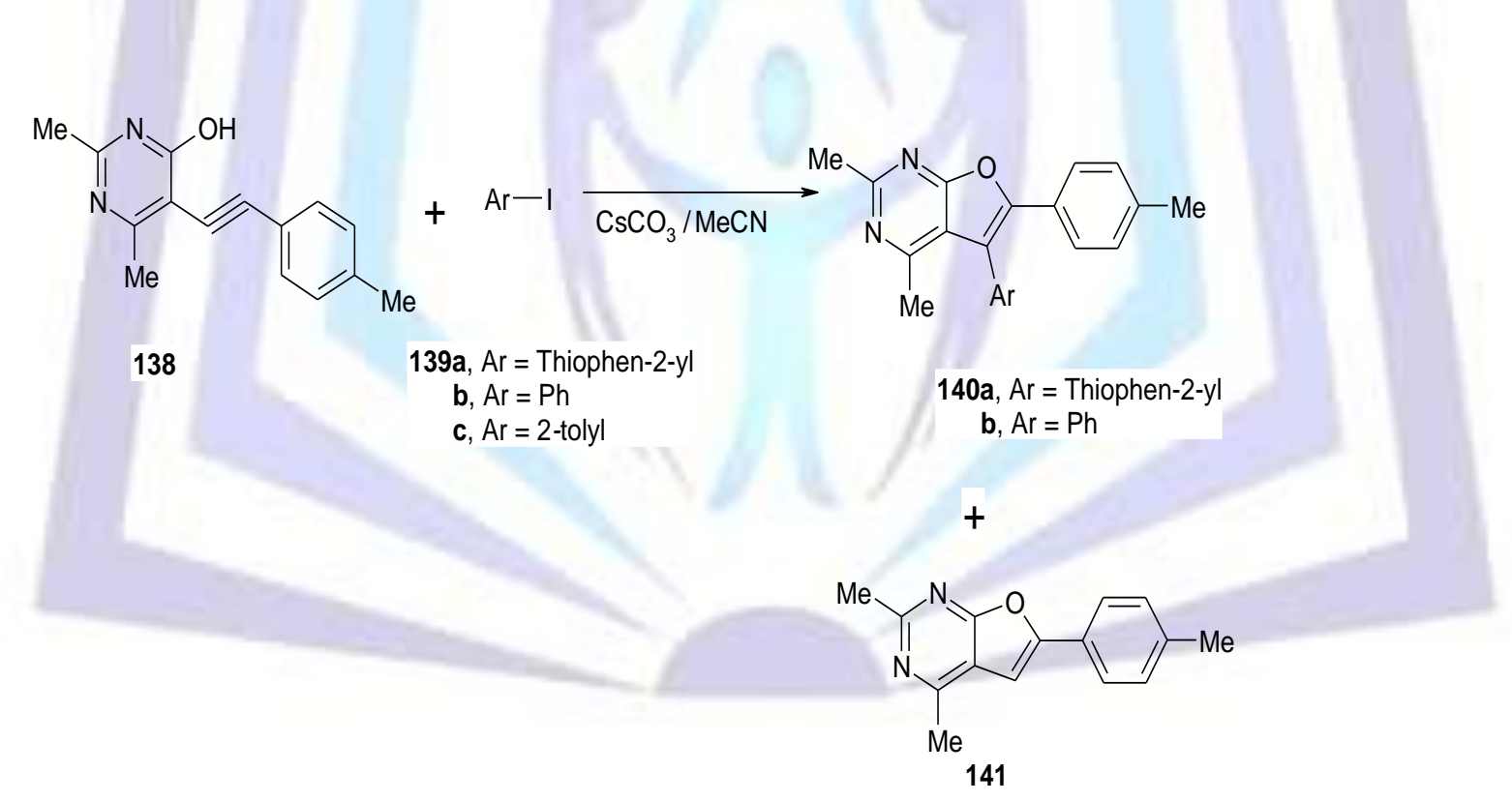

\section{References}

1. Bhuiyan, M. M. H.; Rahman, K. M. M.; Hossain, M. K.; Rahim, M. A.; Hossain, M. I. Croat. Chem Acta. 2005, 78, 633.

2. Gangjee, A.; Zeng, Y.; McGuire, J. J.; Kisliuk, R. L. J. Med. Chem . 2005, 48, 5329.

3. Gangjee, A.; Zeng, Y.; Innat, M.; Warnke, L. A.; Green, D. W.; Kisliuk, R. L.; Lin, F. T. Bioorg. Med. Chem. 2005, 13, 5475.

4. Gangjee, A.; Zeng, Y.; McGuire, J. J.; Mehraein, F.; Kisliuk, R. L. Med. Chem. 2004, 47, 6893.

5.Dave, C. G.; Shah, R. D. Molecules 2002, 7, 554.

6. Janeba, Z.; Balzarini, J.; Andrei, G.; Snoeck, R.; De Clercq, E.; Robins, M. J. J. Med. Chem. 2005, 48, 4690.

7. Robins, M. J.; Miranda, K.; Rajwanshi, V. K.; Peterson, M. A.; Andrei, G.; Snoeck, R.; De Clercq, E.; Balzarini, J. J. J. Med. Chem. 2006, 49, 391. 
8. Hunger, A.; Hoffmann, K. Helv. Acta 1957, 40, 1319.

9. Tomioka, Y.; Ohkubo, Y. K.; Yamazaki, M. Chem. Pharm. Bull. 1985, 33, 1360.

10. Miyazaki, Y.; Matsunaga, S.; Tang, J.; Maeda, Y.; Nakano, M.; Philippe, R. J.; Shibahaa, M.; Liu, W.; Sato, H.; Wang, L.; Nolte, R. T. Bioorg. Med. Lett. 2005, 15, 2203.

11. Maeda, Y.; Nakano, M.; Sato, H.; Miyazaki, Y.; Schweiker, S. L.; Smith, J. L.; Truesdale, A. T. Bioorg. Med. Chem. Lett. 2004, 14, 3907.

12. Gewald, K. Chem. Ber.1966, 99, 1002.

13. Bhuiyan, M. M. H.; Rahman, K. M. M.; Hossain, M. K.; Rahim, M. A.; Hossain, M. I. Croatica Chemica acta 2005, 78, 633.

14. Taylor, E. C.; McKillop, A. Adv. Org. Chem. 1969, 7, 79.

15. Taylor, E. C.; Hartke, K. S. J. Am. Chem. Soc. 1959, 81, 2456.

16. Taylor, E. C.; Knopf, R. J.; Meyer, R. F.; Holmes, A.; Hoefle, M. L. J. Am. Chem. Soc. 1960, 82, 5711.

17. Prousek, J.; Jurãšek, A.; Kovãč, J. Collection Czechoslov. Chem.Commun. 1980, 45, 1581.

18. Abdelrazek, F. M.; Michael, F. A.; El-Mahrouky, S. International Journal of Physical Sciences 2007, $2,212$.

19. Kohler, A. M.; Widmer, J.; Bold, G.; Meyer, T.; Sĕquin, U.; Traxler, P. Helvetica Chemica Acta 2004, 87, 956.

20. Shishoo, C. J.; Devani, M. B.; Bhadti, V. S.; Jain, K. S.; Ananthan, S. J. Heterocyclic Chem. 1990, $27,119$.

21. Temnikova, T.I.; Sharanin, Y. A.; Karavan, V. S. Zh. Org. Khim. 1967, 3, 681.

22. Miyazaki, Y.; Maeda, Y.; Sato, H.; Nakano, M.; Mellor, G.W. Bioorg. Med. Chem. Lett. 2008, 18, 1967.

23. Aly, A. S.; Fathy, N. M.; Swelam, S.A.; Abdel-Megeid, F. M. E. Egypt J. Pharm. Sci. 1995, 36, 177.

24. Shaker, R. M. Arkivoc 2006, 14, 68.

25. Jyothikumari, K. R.; Rajasekharan, K. N. J.Indian. Chem.Soc. 1991, 68, 660.

26. Kidwai, M.; Rastogi, S.; Venkataramanan, R. Bull. Chem. Soc. Jpn 2003, 76, 203.

27, Gewald, K.; Schäfer, H.; Eckert, K.; Jeschke, T. J. Prakt. Chem. 1994, 338, 993.

28. DiMauro, E. F.; Newcomb, J.; Nunes, J. J.; Benis, J. E.; Boucher, C.; Buchanan, J. L.; Buckner, W. H.; Cheng, A.; Faust, T.; Hsieh, F.; Huang, X.; Lee, T. H.; Marshall, T. L.; Martin, M. W.; McGowan, D. C.; Schneider, S.; Turci, S. M.; White, R. D.; Zhu, X. Bioorg. Med.Chem. Lett. 2007, 17, 2305.

29. Maruoka, H.; Yamagata, K.; Yamazaki, M. Liebigs Ann .Chem. 1994, 993.

30. Skibinski, A.; Stec, Z.; Jannuchowski, M.; Parys, L. Appl. Chem. 1993, 37, 291.

31. Morris, P. E.; Elliott, A. J.; Montgomery, J. A. J. Heterocyclic Chem. 1999, 36, 423.

32. Lockhart, C. C.; Sowell, J. W. J. Heterocyclic Chem.1996, 33, 659.

33. Dang, Q.; Liu, Y. Tetrahedron Letters 2009, 50, 6758.

34. Paolini, L.; Petricci, E.; Corelli, F.; Botta, M. Synthesis 2003, 1039.

35. Petricci, E.; Radi, M.; Corelli, F.; Botta, M. Tetrahedron Letters 2003, 44, 918.

36. Tolstikov, G. A.; Mustafin, A. G.; Gataullin, R. R.; Spirikhin, L. V.; Abdrakhmanov ,I. B. Izv. Akad. Nauk SSSR, Ser. Khim., 1449, 1992; Chem. Abstr. 1993, 118, 124938.

37. McGuigan, C.; Brancale, A.; Andrei, G.; Snoeck, R.; De Clercq, E.; Balzarini, J. Bioorg. Med. Chem. Lett. 2003, 13, 4511.

38. Luoni, G.; McGuigan, C.; Andrei, G.; Snoeck, R.; De Clercq, E.; Balzarini, J. Bioorg. Med. Chem. Lett. 2005, $15,3791$.

39. Valdivia, V.; Hernandez, A.; Rivera, A.; Sartillo, F.; Loukaci, A.; Fourrey, J. L.; Quintero, L. Tetrahedron Letters 2005, $46,6511$.

40. Amblard, F.; Aucagne, V.; Gueno, P.; Schinazi, R. F.; Agrofoglio, L.A. Bioorg. Med. Chem. 2005, $13,1239$.

41. Hamano, Y.; Nakamura, T. Jpn. Kokai 89, 6341, 1978; Chem. Abstr. 1978, 78, 12888.

42. Eger, K.; Jalalian, M.; Schmidt, M. J. Heterocycl. Chem. 1995, 32, 211.

43. Quijano, M. L.; Nogueras, M.; Sanchez, A. Nucleosides Nucleotides 11, 121, 1992 ; Chem. Abstr. 1992, $116,194760$.

44. Spada, M. R.; Klein, R. S.; Otter, B. A. J. Heterocycl. Chem. 1989, 26,1755. 
45. Badawey, E. A. M. J. Heterocycl. Chem. 1996, 33, 229.

46. Majumdar, K. C.; Mondal, S. Tetrahedron 2009, 65, 9604.

47. Floppe, N.; Fischer, L. M.; Howes, R.; Kierstan, P.; Potter, A.; Robertson, A. G. S.; urgenor, A. E. J. Med. Chem. 2005, 48, 4332.

48. Dauzonne, D.; Adam-Launay, A. Tetrahedron 1992, 48, 3069.

49. Reisch, J.; Bathe, A. J. Heterocycl. Chem. 1987, 24, 1409.

50. Qian, C.-Y.; Nishino, H.; Kurosawa, K.; Korp, J. D. J. Org. Chem. 1993, 58, 4033.

51. Figueroa-Villar, J. D.; Carneiro, C. L.; Cruz, E. R. Heterocycles 1992, 34, 891.

52. Ahluwalia, V. K.; Tyagi, R.; Kaur, M. Indian J. Chem., Sect. B 29, 566, 1990; Chem. Abstr.1990, $113,191272$.

53. Ahluwalia, V. K.; Sharma, R.; Khanduri, C. H.; Kaur, M.; Gupta, C. Heterocycles 1991, 32, 907.

54. Strekowski, L. J. Heterocycl. Chem. 2001, 38, 359.

55. Goerlittzer, K.; Boventer, K. Arch. Pharm. (Weinheim, Ger.) 325, 333, 1992 ; Chem. Abstr. 1992, 117, 171356.

56. Secrist, J. A.; Liu, P. S. J. Org. Chem. 1978, 43, 3937.

57. Gangjee, A.; Jain, H. D.; Phan, J.; Guo, X..; Queener, S. F.; Kisliuk, R. L. Bioorg. Med. Chem. 2010, $18,953$.

58. Gangjee, A.; Yang, J.; McGuire, J. J.; Kisliuk, R. L. Bioorg. Med.Chem. 2006, 14, 8590.

59. Gangjee, A.; Li, W.; Lin, L.; Zeng, Y.; Ihnat, M.; Warnke, L. A.; Green, D. W.; Cody, V.; Pace, J.; Queener, S. F. Bioorg. Med. Chem. 2009, 17,7324.

60. Gangjee, A.; Zeng, Y.; McGuire, J. J.; Kisliuk, R. L. J. Med. Chem. 2000, 43, 3125.

61. Ramasamy, K.; Robins, R. K.; Revankar, G. R. J. Chem. Soc., Chem. Commun. 1989, 560.

62. Duff, T. D. University of Dublin, 2000.

63. Boyle, P. H.; Ali, H. D. P.; Mc Donald, T. J. Arkivoc 2003, 7, 67.

64. Machon, Z.; Cipelik, J. Synthesis 1986, 142.

65. Strekowski, L.; Wydra, R. L.; Janda, L.; Harden, D. B. J. Org.Chem. 1991, 56, 5610.

66. Lagu, B.; Tian, D.; Chiu, G.; Nagarathnam, D.; Fang, J.; Shen, Q.; Forray, C.; Ransom, R.W.; Chang, R. S. L.; Vyas, K. P.; Zhang, K.; Gluchowski, C. Bioorg. Med. Chem. Lett. 2000, 10, 175.

67. Chiba, T.; Sato, H.; Kato, T. Heterocycles 1984, 22, 493.

68. Cikotiene, I.; Morkunas, M.; Motiejaitis, D.; Rudys, S.; Brukstus, A. Synlett 2008,1693.

69. Cikotiene, I.; Buksnaitiene, R.; Rudys, S.; Morkunas, M.; Motiejaitis, D. Tetrahedron 2010, 66, 251.

70. Liu, Z.; Li, D.; Li, S.; Bai, D.; He, X.; Hu, Y. Tetrahedron 2007, 63, 1931. 